\title{
Newsletter wewnętrzny jako instrument wspomagający realizację strategii zarządzania zasobami ludzkimi. Przykład Urzędu Statystycznego w Kielcach
}

\author{
Agnieszka Piotrowska-Piatek*
}

\begin{abstract}
Artykut poświęcony jest praktycznym aspektom zarzadzania w jednostce administracji publicznej. Podejmuje się $w$ nim problematykę komunikowania wewnętrznego $w$ odniesieniu do wybranych obszarów strategii zarzadzania zasobami ludzkimi (ZZL). Celem autorki jest zaprezentowanie możliwości wykorzystania newslettera pracowniczego jako narzędzia komunikowania wewnętrznego $w$ procesie realizacji strategii $Z Z L$. W trakcie prowadzonych rozważań wykorzystano analize literatury przedmiotu, studium przypadku oraz wyniki badań własnych autorki. Przedstawiony przykład newslettera pracowników Urzędu Statystycznego w Kielcach wydaje się dobra praktyka w procesie komunikowania się wewnętrznego, wspomagająca realizacje strategii $Z Z L$.
\end{abstract}

Słowa kluczowe: zarządzanie zasobami ludzkimi, administracja publiczna, komunikacja wewnętrzna, newsletter wewnętrzny.

Nadesłany: 24.06.2015 | Zaakceptowany do druku: 25.07.2015

\section{Internal newsletter as an instrument for supporting an implementation human resources management strategy. Case study of Statistical Office in Kielce}

The article is dedicated to practical aspects of management in public administration. It discusses the problem of internal communication in relation to selected areas of human resources management (HRM) strategy. The aim of the article is to present opportunities of using an internal newsletter as a form of communication in the HRM strategy implementation. The analysis is conducted on the basis of relevant literature, case study and results of the Authors study. The staff newsletter in the Statistical Office in Kielce presented here seems to be an example of good practice in internal communication supporting implementation of HRM strategy.

Keywords: human resources management, public administration, internal communication, internal newsletter.

Submitted: 24.06.2015 | Accepted: 25.07.2015

JEL: D22, H83, M12

Dr Agnieszka Piotrowska-Piątek - Urząd Statystyczny w Kielcach, Wydział Zarządzania i Modelowania Komputerowego, Politechnika Świętokrzyska.

Adres do korespondencji: Korczyn 27, 26-067 Strawczyn; e-mail: apiotrowskapiatek@gmail.com. 


\section{Wprowadzenie}

Komunikowane się jest jednym z warunków funkcjonowania człowieka w określonych grupach społecznych - rodzinie, grupie szkolnej, zakładzie pracy. Między innymi z tego powodu problematyka ta jest przedmiotem rozważań na gruncie różnych dyscyplin nauk społecznych - psychologii, socjologii, etnografii, ekonomii oraz nauk humanistycznych - nauk o poznaniu i komunikacji społecznej. W odniesieniu do nauk ekonomicznych komunikowanie się jest przedmiotem dyskusji i badań naukowych, przede wszystkim w ramach marketingu (marketing kadrowy, public relations) oraz zarządzania zasobami ludzkimi (motywacja, przywództwo, komunikowanie wewnętrzne, rozwój zasobów ludzkich, zarzadzanie konfliktem).

W niniejszym artykule autorka podejmuje problematykę komunikowania wewnętrznego (zwanego również pracowniczym lub zespołowym) w odniesieniu do wybranych obszarów strategii zarządzania zasobami ludzkimi (ZZL). Pojęcia „,komunikowanie się” i „komunikacja” traktowane są w niniejszej publikacji zamiennie. Autorka przyjmuje powszechnie akceptowaną w literaturze przedmiotu definicję, że jest to proces przekazywania i odczytywania informacji oraz sensu, zachodzacy co najmniej pomiędzy dwoma osobami lub grupami osób (por.: Marfo-Yiadom, 2008, s. 288-289). Podobnie zamiennie traktuje sformułowania ,technika komunikowania” i „narzędzie komunikowania" jako określenia sposobu i zespołu środków (również o charakterze technicznym) dla realizacji procesu komunikowania.

Artykuł składa się z czterech części. Poprzedzony jest wprowadzeniem, a zakończony podsumowaniem. Celem autorki jest zaprezentowanie możliwości wykorzystania newslettera pracowniczego jako narzędzia komunikowania wewnętrznego $\mathrm{w}$ procesie realizacji strategii ZZL. W części teoretycznej, w której zastosowano metodę analizy literatury przedmiotu, przedstawiono znaczenie prawidłowego komunikowania się wewnątrz organizacji w procesie ZZL. Omówiono możliwości i zasady wykorzystania w tym procesie newslettera pracowniczego. W części empirycznej zaprezentowano przykład newslettera pracowników Urzędu Statystycznego w Kielcach. Z uwagi na opisowo-eksploracyjny charakter problemu badawczego zastosowano metodę pojedyn- czego studium przypadku (single case study), opartego na celowym doborze jednostki badanej. Zgodnie $\mathrm{z}$ zasadą triangulacji metodologicznej w tego typu badaniu (Wójcik, 2013) wykorzystano informacje pochodzące z obserwacji uczestniczącej autorki oraz analizę treści dokumentów wewnętrznych (w tym aktów prawa wewnętrznego) i artykułów zamieszczanych w newsleterze. Zaprezentowano również wyniki badania ankietowego, którego celem była ocena przez pracowników analizowanej jednostki funkcji, jakie newsletter spełnia w procesie komunikowania wewnętrznego i wspomagania realizacji strategii ZZL.

\section{Komunikowanie wewnętrzne jako podstawa zarządzania zasobami ludzkimi - implikacje dla jednostek administracji publicznej}

W literaturze przedmiotu można odnaleźć wiele ujęć definicyjnych pojęcia „komunikacja organizacyjna" (korporacyjna). $\mathrm{Na}$ uwagę zasługuje podejście J. Cornellissena, który definiuje komunikację korporacyjną jako funkcję zarządzania, określającą ramy efektywnej koordynacji komunikacji wewnętrznej i zewnętrznej w celu stworzenia i podtrzymania korzystnej reputacji danej organizacji wśród grup interesariuszy, od których ta organizacja jest zależna (Cornelissen, 2010, s. 26).

Nawiązując do przytoczonego podejścia J. Cornellisena, który komunikację organizacji sytuuje wśród funkcji zarządzania, warto wskazać jej cele. E. Marfo-Yiadom, powołując się na N. Allena, wymienia następujące cele, którym służy komunikacja i które stanowią o tym, że jest ona kluczowa w procesie zarządzania organizacją (Marfo-Yiadom, 2008, s. 289):

- komunikując się, wywieramy wpływ na pracę członków organizacji: motywujemy, instruujemy, oceniamy,

- sieci komunikacyjne tworzą ludzie i wiele z tego, co komunikuja, niesie ze sobą tadunek emocjonalny, komunikacja zatem (zarówno formalna, jak i nieformalna) jest podstawowym sposobem wyrażania uczuć,

- dzięki komunikowaniu się zdobywamy informacje niezbędne do sprawowania funkcji menadżerskich,

- struktury komunikacyjne i organizacyjne ściśle się ze sobą wiążą. 
T. Zawadzak zarządzanie komunikacją traktuje jako spoiwo zarządzania wszystkimi zasobami i procesami organizacji (Zawadzak, 2014, s. 53). J. Szaban komunikację określa „krwioobiegiem” organizacji (Szaban, 2011, s. 352).

Jednym z rodzajów komunikacji organizacyjnej jest komunikacja wewnętrzna. Zagadnienie to stosunkowo częściej podejmowane jest przez badaczy wewnętrznego public relations (por. Budzyński, Rozwadowska) niż na gruncie zarządzania zasobami ludzkimi. Dla obydwu jednak perspektyw można odnaleźć wspólne obszary odpowiadające procesom: motywowania pracowników, partycypacji pracowników w zarządzaniu organizacją oraz wspierania ich rozwoju zawodowego.

Właściwe komunikowanie się w organizacji stanowi podstawę procesu ZZL. Realizacja strategii opartej na rozwoju zasobów ludzkich zależy nie tylko od komunikowania nowych rozwojowych wartości, ale w większej mierze od tego, na ile pracownicy rozumieją, w jaki sposób wdrażane wartości przekładają się na ich realną pracę i angażują się w postępujące zmiany (Rogozińska-Pawełczyk, 2014, s. 28).

B. Rozwadowska zwraca uwagę na kolejny ważny aspekt komunikowania wewnętrznego. Współcześnie płaca nie jest już dla pracowników jedynym wyznacznikiem satysfakcji. Pracownicy oczekuja informacji. Dostarczając ją, okazuje im się zaufanie i szacunek, dzięki czemu wzrasta poziom ich motywacji do pracy. Pracownicy chcą być traktowani jak równorzędny partner, który ma swój udział w rozwoju organizacji (Rozwadowska, 2002, s. 119).

Przemyślane działania z zakresu komunikacji wewnętrznej są doceniane i zauważane przez pracowników, świadczą o trosce i zaangażowaniu zarządzających $\mathrm{w}$ dobre relacje $\mathrm{w}$ zespole i pokazują wolę informowania pracowników o tym, co się dzieje w organizacji. A. Orlińska zwraca również uwage, że prowadzenie działań z zakresu komunikacji wewnętrznej leży w interesie samego pracodawcy. Sprawne porozumiewanie się między pracownikami, a zwłaszcza kierownictwem i podwładnymi, nie tylko służy lepszemu wykonywaniu zadań, ale także podnosi efektywność pracy i wzmacnia poczucie tożsamości zatrudnionych. Osoby skutecznie włączone w system komunikacji wewnętrznej bardziej angażują się w pracę, mocniej utożsamiają się $\mathrm{z}$ organizacją oraz są mniej skłonne zmienić pracodawcę. W rezultacie przekłada się to na zmniejszenie kosztów związanych z pozyskaniem nowego, wartościowego pracownika, przeszkolenie go i wdrożenie w pracę poprzednika (Orlińska, 2010).

W jednostkach administracji publicznej podstawowym zasobem są ludzie (Rostkowski, 2012, s. 11). Zdolność do kształtowania i efektywnego wykorzystania tego zasobu jest postrzegana jako klucz do sukcesu funkcjonowania tych organizacji (por. Sobolewska-Noel, 2013, s. 26).

Nieodłącznym elementem działań kadrowych w jednostkach administracji publicznej powinien być proces komunikowania. Sprawny system komunikowania to klucz do budowania pozytywnej i przyjaznej atmosfery pracy. Jedna $\mathrm{z}$ podstawowych zależności jest związek poczucia doinformowania $\mathrm{z}$ zadowoleniem i pozytywnym postrzeganiem organizacji. Pracownicy, którzy maja poczucie doinformowania, są bardziej zadowoleni z pracy, bardziej dumni z pracy w urzędzie, chętniej polecają go swoim bliskim, lepiej oceniają swoją organizację, są mniej chętni do zmiany pracodawcy. Mnogość i różnorodność informacji krążących w systemie organizacyjnym jednostek administracji publicznej sprawia, że dla jego właściwego funkcjonowania kluczowe staje się odpowiednie zarządzanie procesem komunikacyjnym (Kształtowanie, s. 14-15), w tym dobór form komunikowania się.

Możliwe do osiągnięcia korzyści w komunikacji wewnętrznej zależą przede wszystkim od właściwie dobranych przekazów trafiających do pracowników za pomoca instrumentów przez nich akceptowanych (Welch, 2012, s. 246). Wśród technik komunikacji wewnętrznej W. Budzyński wymienia: intranet, pocztę elektroniczną, wydawnictwa firmowe (np. podręcznik wprowadzający pracownika $\mathrm{w}$ pracę $\mathrm{w}$ organizacji, gazetę firmową, kronikę firmowa), tablice ogłoszeń, imprezy okolicznościowe, życzenia okolicznościowe i gratulacje, radiowęzeł, skrzynkę życzeń i zażaleń, wydarzenia specjalne, rekreację, konkursy dla pracowników, serwis telefoniczny, system komunikacji bezpośredniej, przemówienia do pracowników, spotkania bezpośrednie, komitety zakładowe (formacje pracownicze), konferencje i spotkania personelu, wizyty zarządu, wzajemne wizyty 
personelu średniego szczebla, imprezy dla pracowników, kluby i stowarzyszenia, korespondencję okolicznościową, znaczki służbowe, uniformy firmowe i karty służbowe, ulotki, programy motywacyjne (Budzyński, 2008, s. 150-152). Niektóre z przywołanych narzędzi mają charakter obowiązkowy, inne fakultatywny, jeszcze inne są efektem inicjatywy samych pracowników.

Należy zauważyć, że w przypadku jednostek administracji publicznej możliwości wykorzystania wyżej wymienionych form komunikowania wewnętrznego są ograniczone $\mathrm{z}$ uwagi na ograniczenia budżetowe (finansowe) oraz sam charakter pracy (służba publiczna, motywacja pracowników typu Public Service Motivation, bardziej sformalizowane stosunki pracy, kultura organizacyjna mocno określona poprzez normatywy postępowania).

\section{Newsletter pracowniczy w komunikowaniu wewnętrznym organizacji}

Niedocenianym przez kadrę zarządzajaca narzędziem komunikowania jest newsletter pracowniczy. W opinii autorki w literaturze przedmiotu z zakresu komunikowania organizacyjnego nie poświęca się temu narzędziu dostatecznej uwagi. Wykorzystanie newslettera w komunikacji wewnętrznej charakterystyczne jest raczej dla praktyki organizacji gospodarczych, korporacyjnych niż dla jednostek sektora publicznego.

Gazeta zakładowa (zwana również newsletterem wewnetrznym, firmowym, gazetą pracowniczą lub zakładową) zaliczana jest przez J. Trębeckiego do grupy narzędzi „od zarządu w dół” (Trębecki, 2007, s. 118). Należy jednak zauważyć, że gazetki mogą być wykorzystywane również w tzw. komunikowaniu w górę (od pracowników do kierownictwa) i „w bok" (pomiędzy pracownikami i grupami pracowników).

Ogólny cel gazety pracowniczej określa się zazwyczaj jako dostarczenie bieżących, aktualnych informacji o organizacji oraz zaspokojenie zapotrzebowania na informacje ze strony pracowników. Traktując to zagadnienie bardziej szczegółowo, można wyróżnić następujące cele newsletterów firmowych (Wojcik, 2005, s. 742-743; por.: Wilk, 2004):
- kształtowanie kultury organizacyjnej zorientowanej na otoczenie,

- tworzenie pozytywnego wizerunku organizacji jako pracodawcy,

- wzmacnianie motywacji pracowników do dobrej pracy,

- popieranie rozwoju karier zawodowych,

- wyjaśnianie problemów organizacji, szczególnie spraw spornych, na temat których krążą rozmaite poglądy,

- poprawa klimatu w organizacji w relacjach kierownictwo-pracownicy,

- popieranie rozwoju zainteresowań pracowników, głównie w czasie wolnym od pracy.

W odniesieniu do procesu wewnętrznego komunikowania się gazeta pracownicza charakteryzuje się następującymi zaletami:

- jest jawna, ponieważ wszyscy pracownicy otrzymują te same informacje bez względu na miejsce $\mathrm{w}$ hierarchii organizacyjnej; w przypadku mocno hierarchicznych struktur i charakteru stosunku pracy w administracji publicznej cecha ta jest szczególnie ważna,

- ma charakter ciągły, informacje docierają do personelu nieprzerwanie, $w$ stale określonych odstępach czasu (z reguły miesięcznych, czasami dwumiesięcznych bądź kwartalnych),

- jest atrakcyjna dla pracowników z uwagi na atrybut dobrowolności (atrybut dobrowolności w przypadku zachowań pracowniczych urzędników mocno określonych przepisami prawa i zasadami jest szczególnie ważną cechą),

- jest aktualna, na jej łamach omawiane są bieżące, ważne sprawy, najbardziej interesujące $\mathrm{z}$ punktu widzenia pracowników.

Oprócz informowania gazety pracownicze pełnia również ważna funkcję integracyjną. Nie chodzi tu jednak o integrację strukturalną, lecz psychologiczną. Ich zadaniem jest ukazanie całego spektrum życia organizacji, stąd też można w nich znaleźć na przykład opis życia socjalnego firmy (Rozwadowska, 2002, s. 127).

M. Sidor-Rządkowska zwraca uwage, że skuteczność wewnętrznej gazetki zależy w dużej mierze od tego, czy jest postrzegana przez pracowników jako źródło interesujących i ważnych informacji oraz powszechnej jej dostępności (Sidor-Rządkowska, 2013, s. 39). 


\section{Komunikowanie wewnętrzne w procesie zarządzania zasobami ludzkimi w Urzedzie Statystycznym w Kielcach}

Urzędy statystyczne są jednostkami administracji niezespolonej, należą do służb statystyki publicznej i podlegają Prezesowi GUS. Urząd Statystyczny w Kielcach obejmuje swoim zasięgiem działania obszar województwa świętokrzyskiego w zakresie m.in.: obsługi rejestrów urzędowych REGON i TERYT, prowadzenia i realizowania badań wynikających z programu badań statystyki publicznej, udostępniania i rozpowszechniania wynikowych informacji statystycznych, popularyzacji i promocji statystyki oraz upowszechniania wiedzy o statystyce, współpracy z organami administracji rządowej oraz organami samorządu terytorialnego.

W Urzędzie zatrudnionych jest obecnie 172 pracowników. Ze struktury zatrudnienia widać, że typowym pracownikiem Urzędu jest kobieta w przedziale wiekowym pomiędzy 31. a 50, rż., z wykształceniem wyższym, stażem pracy powyżej 15 lat, zatrudniona na stanowisku specjalistycznym w Korpusie Służby Cywilnej.

Zgodnie z Zarządzeniem nr 3 Szefa Służby Cywilnej z dnia 30 maja 2012 r. w sprawie standardów zarzadzania zasobami ludzkimi w stużbie cywilnej, a także w celu doskonalenia polityki zarządzania zasobami ludzkimi w Urzędzie opracowano Program Zarzadzania Zasobami Ludzkimi na lata 2013-2015 (wprowadzony poleceniem służbowym dyrektora). Intencją autorów Programu było przygotowanie użytecznego i mającego wymiar aplikacyjny dokumentu. Dlatego też etapem wstępnym do stworzenia Programu była diagnoza, która objęła: strukturę zatrudnienia organizację zarządzania, nabór do służby cywilnej oraz przyjęcia do pracy poza korpusem, systemy ocen, szkoleń i rozwoju zawodowego, mechanizmy motywacji, wynagrodzenia oraz fluktuacje zatrudnienia.

W ramach strategii ZZL w Urzędzie Statystycznym w Kielcach za najistotniejsze cele uznaje się:

- zagwarantowanie odpowiedniego potencjału zasobów ludzkich, tj. wykwalifikowanych, kompetentnych i zmotywowanych pracowników;

- zwiększenie efektywności funkcjonowania pracowników w ramach spójnie i nowocześnie zarządzanej organizacji;
- wzmocnienie wizerunku Urzędu jako pracodawcy i stworzenie sprzyjających warunków do realizacji zawodowej pracowników;

- stworzenie instytucji przyjaznej dla klienta (sprawozdawcy, respondenta, osób i podmiotów korzystających z zasobów informacyjnych statystyki publicznej) i pracownika.

W Programie wyodrębniono następujące obszary funkcjonalne: organizacja ZZL, nabór i wprowadzenie do pracy, motywowanie, rozwój i szkolenia, rozwiązanie stosunku pracy. W każdym obszarze zdefiniowano cele szczegółowe oraz konkretne działania, wyznaczono czas realizacji oraz przyjęto wskaźniki monitoringu.

Jak przedstawiono w pierwszej części artykułu, prawidłowa realizacja wszystkich funkcji personalnych wymaga sprawnego wewnętrznego systemu komunikowania. Stosowane w Urzędzie instrumenty komunikacji wewnętrznej wynikają $\mathrm{z}$ tego, że omawiana organizacja jest jednostka administracji publicznej, a także uwarunkowane są określoną kulturą organizacyjną i realizowaną strategią ZZL. Podzielić można je następująco:

- instrumenty związane $\mathrm{z}$ zapewnieniem i realizacja formalnego ładu wewnętrznego, m.in.: zarządzenia wewnętrzne dyrektora, polecenia służbowe, procedury, wytyczne, godziny dyżuru dyrektora Urzędu, instytucja męża zaufania, zebrania problemowe, spotkania dyrektora $\mathrm{z}$ pracownikami $\mathrm{w}$ ramach okresowej oceny pracowniczej, formacje pracownicze (np. Komisja socjalna),

- instrumenty miekkie, zwiazane bezpośrednio z kształtowaniem pożądanej kultury organizacyjnej i realizacja strategii ZZL, m.in.: Intranet (portal korporacyjny), poczta elektroniczna, newsletter pracowniczy, standardy, zasady, zebrania, spotkania okolicznościowe i integracyjne, życzenia okolicznościowe i gratulacje, nagrody, formacje pracownicze (np. Zespół ds. standardów obsługi klienta).

Powyższy podział ma oczywiście charakter umowny. Niektóre instrumenty wskazane jako zapewniające formalny ład wewnętrzny, i które rodzą skutki o charakterze normatywnym dla pracowników, również mają na celu realizację przyjętej polityki ZZL. Należy dodać, że zaprezen- 
towana lista nie wyczerpuje wszelkich stosowanych form komunikacji, szczególnie w ujęciu horyzontalnym (relacje pomiędzy pracownikami i grupami pracowniczymi) i nielinearnym. Przykłady te dają jednak pogląd, że w procesie komunikowania wewnętrznego w Urzędzie wykorzystywane są różnorodne i zróżnicowane instrumenty.

\section{Newsletter pracowników} Urzędu Statystycznego w Kielcach

Jednym z instrumentów komunikacji wewnętrznej, wspomagającym realizację przyjętego programu ZZL w Urzędzie, jest newsletter pracowniczy. Z uwagi na specyfikę pracy wydawany jest $\mathrm{w}$ formie elektronicznej i publikowany na portalu korporacyjnym. Taki sposób publikacji nie generuje kosztów związanych z tradycyjnymi wydawnictwami, a umieszczony w intranetowym repozytorium jest dostępny cały czas, co, jak pokazują światowe badania, zyskuje uznanie wśród pracowników (Welch, 2012, s. 251). Newsletter w obecnej formule jest wydawany od trzech lat, regularnie, w miesięcznych odstępach czasu. Redagowany jest przez pracowników dwóch wydziałów, które zaangażowane są w realizację programu ZZL oraz polityki komunikowania się $\mathrm{z}$ otoczeniem. W pracach nad newsletterem uczestniczy również kadra zarządzająca i pracownicy innych wydziałów.

W strukturze newslettera można wyróżnić elementy (rubryki) o charakterze stałym oraz periodycznym, w zależności od bieżących potrzeb. Artykuły są krótkie i pisane przystępnym językiem.

Newsletter, w intencji kadry zarządzającej, ma pełnić funkcje nie tylko informacyjne, lecz także motywacyjne, integracyjne i wspomagające rozwój zawodowy pracowników. Zaspokaja zatem, oprócz potrzeb poznawczych, również potrzeby ekspresji emocjonalnej, afiliacji (grupa zawodowa), bezpieczeństwa (w zakresie dostępu do informacji), samorealizacji. W tabeli 1 przedstawiono funkcje, jakie newsletter spełnia wraz z podaniem przykładowych rubryk oraz tematyki artykułów, które wpisują się w realizację danej funkcji.

Layout newslettera, utrzymany w nowoczesnej kolorystce i formie graficznej, ma charakter względnie stały. W zależności od

Tabela 1. Funkcje wewnętrznego newslettera pracowników Urzędu Statystycznego w Kielcach

\begin{tabular}{|l|l|l|}
\hline Realizowana funkcja w kontekście ZZL & Przykłady rubryk & \multicolumn{1}{|c|}{$\begin{array}{c}\text { Przykładowe tytuły/tematy } \\
\text { artykułów }\end{array}$} \\
\hline $\begin{array}{l}\text { Informacyjna (bieżąca informacja, } \\
\text { zapowiedzi i uzasadnienia dla } \\
\text { wprowadzanych zmian) }\end{array}$ & $\begin{array}{l}\text { Rubryka dyrektora; } \\
\text { Z prac Wydziałów; } \\
\text { O tym, co robimy } \\
\text { dla innych; } \\
\text { Seminaria. } \\
\text { Konferencje; } \\
\text { Źakładowego Funduszu } \\
\text { Swiadczeń Socjalnych; } \\
\text { System Elektronicznego } \\
\text { Obiegu Dokumentów oczami } \\
\text { użytkownika; }\end{array}$ \\
$\begin{array}{l}\text { Procesy - cele - kompetencje, } \\
\text { czyli zintegrowane zarządzanie } \\
\text { w Urzędzie }\end{array}$ \\
\hline $\begin{array}{l}\text { Motywacyjna (zachęcanie do rozwojuinien; } \\
\text { zawodowego i osobistego, wzmacnianie } \\
\text { pożądanych postaw) }\end{array}$ & $\begin{array}{l}\text { Sukcesy naszych } \\
\text { pracowników; } \\
\text { Zasje naszych } \\
\text { pracowników }\end{array}$ & $\begin{array}{l}\text { zoktorant na finiszu; } \\
\text { Jak odnaleźć się w utytułowanym } \\
\text { świecie ekspertów, czyli wrażenia } \\
\text { z konferencji naukowej }\end{array}$ \\
\hline $\begin{array}{l}\text { Integracyjna (budowanie klimatu } \\
\text { współpracy, kreowanie wizerunku } \\
\text { instytucji nowocześnie zarządzanej } \\
\text { i przyjaznej dla pracownika, wzmacnianie } \\
\text { spójności grup zawodowych) }\end{array}$ & $\begin{array}{l}\text { Rubryka dyrektora; } \\
\text { Z życia Urzędu }\end{array}$ & $\begin{array}{l}\text { Życzenia okolicznościowe } \\
\text { (np. z okazji Dnia Służby } \\
\text { Cywilnej); } \\
\text { Ale ubaw - dowcipy o urzędnikach }\end{array}$ \\
\hline
\end{tabular}

Źródło: opracowanie własne. 
Rysunek 1. Struktura respondentów z uwagi na aktywność czytelniczą względem newslettera ( $\mathrm{N}$-71)

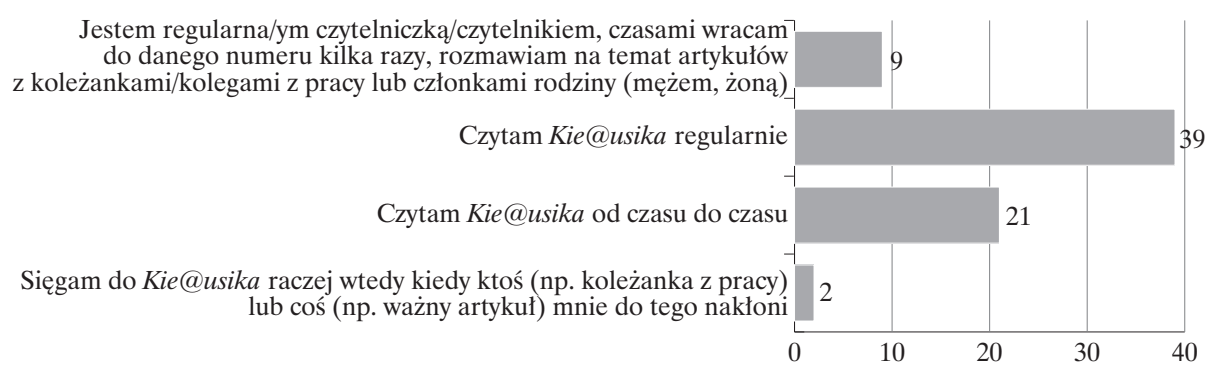

Źródło: opracowanie własne na podstawie wyników badania.

Rysunek 2. Struktura ocen stwierdzenia „Kie@usik informuje mnie, co dzieje się w Urzędzie” (N-71)

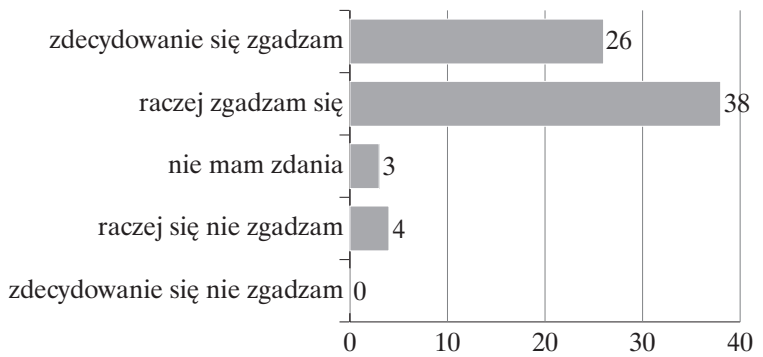

Źródło: opracowanie własne na podstawie wyników badania.

pór roku lub okoliczności konstrukcja graficzna i kolorystyczna jest wzbogacana, tak aby podkreślała prezentowane treści.

W celu oceny funkcji, jakie spełnia newsletter w procesie komunikacji wewnętrznej w Urzędzie, przeprowadzono indywidualne badanie ankietowe metodą CAWI (przy wykorzystaniu narzędzi Google Docs). Ankieta była skierowana do wszystkich pracowników Urzędu i była aktywna w dniach 15-20 lutego 2015 roku. Uzyskano 71 wypełnionych ankiet, co odpowiada $56,8 \%$ pracowników, dla których komputer $\mathrm{z}$ dostępem do Internetu jest podstawowym narzędziem pracy. W kwestionariuszu ankiety zastosowano skalę opisową oraz pięciostopniową skalę Likerta, która jest najczęściej wykorzystywana do badania i pomiaru postaw.

Celem dwóch pierwszych pytań z kwestionariusza ankiety było określenie typowych w zakresie aktywności czytelniczej pracowników. Ponad $67 \%$ respondentów czyta newsletter regularnie (w tym ponad $12 \%$ wykazuje duże zainteresowanie Kie@usikiem, wyrażające się np. wracaniem do danego numeru), a prawie $30 \%$ od czasu do czasu (rysunek 1). 38\% badanych czyta cały numer, a ponad $53 \%$ przegląda cały numer i czyta artykuły wybiórczo. 8,5\% badanych czyta wybrane, ulubione rubryki.

Kolejne pytania w kwestionariuszu odnosiły się do oceny funkcji, jakie newsletter pełni w komunikacji wewnettrznej w Urzędzie. Ponad $90 \%$ badanych zgadza się ${ }^{1}$ ze stwierdzeniem, że „Kie@usik informuje mnie, co się dzieje w Urzędzie" (rysunek 2).

Newsletter firmowy może być płaszczyzną omawiania zmian, wyjaśniania kwestii spornych czy też prezentacji powodów podjęcia przez kadrę zarządzającą określonych decyzji. Poproszono zatem respondentów o ocenę stwierdzenia „Kie@usik pomaga mi zrozumieć zmiany w Urzędzie". Jak widać $\mathrm{z}$ danych przedstawionych na rysunku 3, ponad $53 \%$ respondentów zgadza się z tym stwierdzeniem ${ }^{2}$. Wydaje się zatem, że w przypadku wprowadzania zmian i przekazywania informacji pracownikom na ten temat, newsletter może pełnić funkcję pomocniczą względem innych form komunikowania wewnętrznego. $\mathrm{Z}$ pewnością nie może zastąpić bezpośredniego kon- 
Rysunek 3. Struktura ocen stwierdzenia „Kie@usik pomaga mi zrozumieć zmiany w Urzędzie” (N-71)

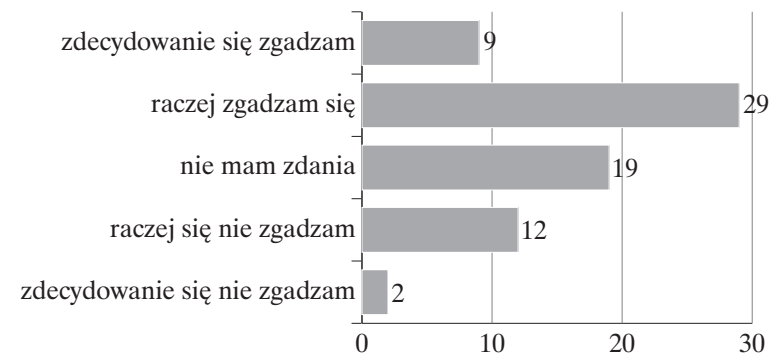

Źródło: opracowanie własne na podstawie wyników badania.

taktu, pozwalającego na interakcję i dodatkowe wyjaśnienia.

Jedną z zakładanych przez kadrę zarzadzającą Urzędu funkcji newslettera jest wspomaganie procesów pobudzania rozwoju zawodowego pracowników, tworzenie pozytywnego klimatu wokół postaw otwartych na ciaggłe doskonalenie się. Stałym elementem każdego numeru są zatem informacje na temat sukcesów zawodowych pracowników. Dla ponad 52\% respondentów lektura takich artykułów jest czynnikiem motywującym do pracy $^{3}$ (rysunek 4), a dla prawie $48 \%$ również do indywidualnego rozwoju zawodowego.

Ważnym celem strategii ZZL w Urzędzie jest budowanie dobrego klimatu pracy w Urzędzie. Ponad 57\% respondentów zgadza się ze stwierdzeniem, że newsletter pomaga w realizacji tego celu, prawie $33 \%$ respondentów nie ma na ten temat zdania, a niecałe $9 \%$ jest odmiennego zdania.

W świetle zaprezentowanych powyżej wyników nie ulega wątpliwości, że newsletter w opinii pracowników jest istotnym instrumentem komunikacji wewnętrznej w Urzędzie, który wspomaga realizację strategii ZZL.

\section{Wnioski}

Komunikacja wewnętrzna jest podstawowym warunkiem egzystencji każdej organizacji. Ludzie, jako istoty społeczne, komunikują się bowiem ze sobą nie tylko w celu zaspokojenia swoich indywidualnych potrzeb, ale również by utrzymać i rozwijać tworzone przez siebie organizacje (Stor, 2010, s. 381).

Właściwie prowadzona komunikacja wewnętrzna jest platformą nowoczesnego zarządzania, ponieważ wzbudza zaufanie i przeciwdziała izolacji, porządkuje działania, ale też nadaje im głębszy sens. Komunikacja wewnętrzna sprzyja również wzrostowi efektywności pracy. Poinformowani pracownicy czują się ważni i wartościowi, lepiej zmotywowani do wykonywania powierzonych im zadań. Utożsamiają się z organizacją i mają poczucie odpowiedzialności za nią. Częśsiej też wykazują się własną inicjatywą (Rozwadowska,

Rysunek 4. Struktura ocen stwierdzenia „Artykuły o sukcesach zawodowych koleżanek i kolegów motywują mnie do pracy" (N-71)

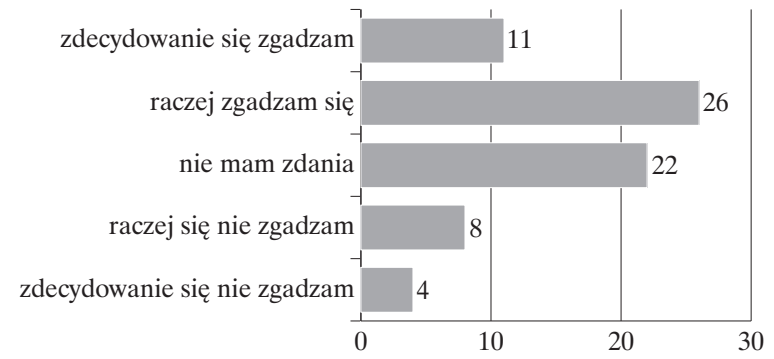

Źródło: opracowanie własne na podstawie wyników badania. 
2002, s. 120). Efektywna komunikacja pozytywnie wpływa na relacje, wzmacnia zachowanie zorientowane na cel i pomaga stworzyć więzi zaufania pomiędzy ludźmi pracującymi w organizacyjnych grupach (Marfo-Yiadom, 2008, s. 288).

Komunikacja wewnetrzna w organizacji według badań przeprowadzonych metodą delficką wśród liderów europejskich stowarzyszeń komunikacji wewnętrznej jest postrzegana jako interdyscyplinarna funkcja zarządzania, integrująca elementy zarządzania zasobami ludzkimi, komunikowania się i marketingu (Tkalac-Vercic, Vercic i Sriramesh, 2012).

Pod adresem zarządzania zasobami ludzkimi w jednostkach administracji publicznej formułuje się wiele uwag krytycznych. Jak pisze M. Sidor-Rządkowska, wciąż jeszcze funkcjonuja instytucje, w których, obserwując działania związane z kierowaniem ludźmi, można odnieść wrażenie, że czas się zatrzymał (Sidor-Rządkowska, 2013, s. 9). Na tym tle zaprezentowany w artykule przypadek Urzędu Statystycznego w Kielcach wydaje się pozytywnie wyróżniającym się przykładem jednostki administracji publicznej.

Jak przedstawiono $\mathrm{w}$ artykule, niezbędnym elementem $w$ procesie ZZL w jednostkach administracji publicznej jest właściwa komunikacja wewnętrzna. Wykorzystując odpowiednio dobrane do tego typu organizacji instrumenty komunikowania, kadra zarzadzająca ma możliwość kształtowania pożąanych postaw pracowników, wzmacniania ich identyfikacji z grupą zawodową, pobudzania rozwoju zawodowego i osobistego oraz kreowania właściwego klimatu pracy. Jak zauważa J. Szaban, istotne jest wykorzystanie nowoczesnych narzędzi komunikowania przy jednoczesnym niezaniedbywaniu komunikacji bezpośredniej (Szaban, 2011, s. 352). W jednostkach administracji publicznej katalog możliwych instrumentów komunikowania się jest ograniczony w porównaniu do sektora przedsiębiorstw, z uwagi na ograniczenia zarówno formalne, jak i finansowe. Należy również zwrócić uwagę, że zarządzanie organizacjami publicznymi charakteryzuje mniejsza autonomia kadry zarządzającej (Kożuch, 2004, s. 94), co ma wpływ na realizację poszczególnych strategii funkcjonalnych (m.in. ZZL).

Przedstawiony w artykule przykład newslettera jest skutecznym narzędziem w procesie komunikowania się wewnętrznego organizacji. Świadczy o tym również wyróżnienie go jako dobrej praktyki, rozwiązania wspierającego procesy zarządcze, w ramach projektu realizowanego przez firmę PWC na zlecenie Kancelarii Prezesa Rady Ministrów w latach 2014-2015 Procesy. Cele. Kompetencje. Zintegrowane Zarzadzanie w Urzędzie (PWC, 2015, s. 83-84). Wyniki zaprezentowanego badania ankietowego pokazują, że w opinii pracowników jest dobrym komunikatorem a jego charakter i struktura wpisują się w realizację celów strategii ZZL w Urzędzie.

\section{Przypisy}

1 Odpowiedzi: „zdecydowanie się zgadzam” i „raczej się zgadzam”.

2 Odpowiedzi: „zdecydowanie się zgadzam” i „raczej się zgadzam".

3 Odpowiedzi: „zdecydowanie się zgadzam” i „raczej się zgadzam”.

\section{Bibliografia}

Budzyński, W. (2008). Public relations. Strategia $i$ nowe techniki kreowania wizerunku. Warszawa: Poltext.

Cornelissen, J. (2010). Komunikacja korporacyjna: przewodnik po teorii i praktyce. Warszawa: Wolters Kluwer Polska

Kożuch, B. (2004). Zarządzanie publiczne w teorii i praktyce polskich organizacji. Warszawa: Wydawnictwo Placet.

Ksztattowanie procesu komunikacji wewnętrznej w urzedzie, http://www.kruszyna.com/aktualnosci/ caf_podrecznik.pdf (01.03.2015).

Marfo-Yiadom, E. (2008). Zasady zarzadzania. Łódź: Wydawnictwo Wyższej Szkoły Humanistyczno-Ekonomicznej w Łodzi.

Orlińska, A. (2010). Zainteresuj, zaangażuj, przyzwyczaj, czyli jak przygotować magazyn wewnętrzny, http://www.proto.pl/artykuly/zainteresuj-zaangazujprzyzwyczaj-czyli-jak-przygotowac-magazynwewnetrzny (01.03.2015).

PWC (2015). Vademecum skutecznego wdrażania zmian. Warszawa.

Rogozińska-Pawełczyk, M.A. (2014). Komunikacja jako narzędzie rozwoju zasobów ludzkich. Zarzadzanie Zasobami Ludzkimi, 1.

Rostkowski, T. (2012). Strategiczne zarządzanie zasobami ludzkimi $w$ administracji publicznej. Warszawa: Wolters Kluwer Polska.

Rozwadowska, B. (2002). Public Relations. Teoria. Praktyka. Perspektywy. Warszawa: Wydawnictwo Studio Emka. 
Sidor-Rządkowska, M. (2013). Zarzadzanie zasobami ludzkimi $w$ administracji publicznej. Ocena i rozwój członków korpusu stużby cywilnej. Warszawa: LEX a Wolters Kluwer business.

Sobolewska-Noel, J. (2013). Rynkowe trendy i koncepcje w dziedzinie zarządzania w administracji publicznej jako odpowiedź na potrzeby reform współczesnej administracji publicznej. Zarządzanie Publiczne, 1(21).

Stor, M. (2010). Komunikowanie się w organizacji. W: T. Listwan (red.), Zarzadzanie kadrami. Warszawa: Wydawnictwo C.H. Beck.

Szaban, J. (2011). Zarzadzanie zasobami ludzkimi $w$ biznesie $i w$ administracji publicznej. Warszawa: Difin.

Tkalac-Vercic, A., Vercic, D. i Sriramesh, K. (June 2012). Internal communication: Definition, parameters and the future. Public Relations Review, 38(2)

Trębecki, J. (2007). Relacje wewnętrzne. W: J. Olędzki i D. Tworzydło (red.), Public relations.
Znaczenie spoteczne i kierunki rozwoju. Warszawa: Wyższa Szkoła Informatyki i Zarządzania w Rzeszowie: Wydawnictwo Naukowe PWN.

Urząd Statystyczny w Kielcach (2013). Program Zarzadzania Zasobami Ludzkimi na lata 2013-2015. Kielce.

Welch, M. (2012). Appropriateness and Acceptability: Employee Perspectives in Internal Communication. Public Relations Review, 38.

Wilk, K. (2004). Gazeta firmowa. Zastosowanie metody określania ról pracowników $w$ redagowaniu biuletynu wewnętrznego przedsiębiorstwa, http://www. proto.pl/artykuly/gazeta-firmowa (01.03.2015)

Wojcik, K. (2005). Public relations. Wiarygodny dia$\log$ z otoczeniem. Warszawa: Placet.

Wójcik, P. (2013). Znaczenie studium przypadku jako metody badawczej w naukach o zarządzaniu. E-mentor, 1(48).

Zawadzak, T. (2014). Zarzadzanie $w$ organizacjach sektora publicznego. Warszawa: Difin. 